\title{
Childhood Cancer Incidence in Cuba, 2001 to 2003
}

\author{
Priscila Torres, MD, Yaima Galán, MPH, Juan Lence, MD, MPH, Mariela García, DDS, MPH, Martha Lezcano, \\ Leticia Fernández, MD, PhD
}

\begin{abstract}
Introduction Estimating childhood cancer incidence globally is hampered by lack of reliable data and uniform age limits for classifying and analyzing data reported. In Cuba, cancer data has been systematically gathered and processed by the National Cancer Registry (NCR) since 1964. The International Classification of Childhood Cancer (ICCC) is currently recommended for registering neoplasms in the population aged $\leq 19$ years. Cancer incidence data published by the Cuban Ministry of Public Health, however, uses ICCC diagnostic groups for the population aged $<15$ years, and topographic sites for the population aged $\geq 15$ years.
\end{abstract}

Objective The objectives of this study are to describe cancer incidence in the Cuban population aged $\leq 19$ years in 2001-2003 using the ICCC, as well as geographic distribution of incidence by sex and by principal diagnostic groups.

Methods A descriptive study of cancer incidence in the population aged $\leq 19$ years was conducted using NCR data for 2001-2003. ICCC diagnostic groups and subgroups were used, and 5 age groups $(<1$, $1-4,5-9,10-14$ and 15-19 years) were analyzed. Total incidence and percentages for each diagnostic group were calculated. Number of cases in each diagnostic group and subgroup was also recorded by

\section{INTRODUCTION}

Worldwide, it is estimated that more than 160,000 children aged $<14$ years are diagnosed with cancer every year, although this figure may be low given lack of reliable data, even in developed countries. An estimated $80 \%$ of these children live in developing countries, a proportion expected to increase with improved prevention and control of infectious diseases.[1] In Cuba, cancer is the second leading cause of death in the population aged 1-19 years and the main cause of years of potential life lost (17.5 years in 2008).[2]

The main reason estimates of childhood cancer incidence are imprecise is that many countries-developed as well as undeveloping-do not have national cancer registries.[1,3-5] Analyzing reported incidence rates is further complicated by the lack of a uniform definition of childhood with standard age limits in different countries, registries and studies.[6] Childhood cancer incidence is often reported per population aged $<15$ years; this age cutoff makes registration of cases diagnosed in adolescents difficult, creating in turn a major problem for epidemiological analysis of cancer in the population aged 15-19 years.

Neoplasms in children are classified by morphology (histology), according to the International Classification of Childhood Cancer (ICCC), whereas in adults, they are classified primarily by topography (site), according to the International Classification of Diseases for Oncology (ICD-O).[7] In children aged $<15$ years, 92\% of neoplasms are non-epithelial and only $8 \%$ epithelial. Between the ages of 15 and 19 years, a transition towards an inverse situation begins, so that between the ages of 30 and 45 years, $80 \%$ of neoplasms are epithelial, reaching $90 \%$ with increasing age.[8] age group, and age-specific rates per 100,000 population aged $\leq 19$ years (ASR) and age-adjusted rates to the standard world population aged $\leq 19$ years (AAR) were calculated. AARs for leukemias, lymphomas and central nervous system (CNS) tumors were used to analyze childhood cancer risk by sex and geographical distribution in the country's 14 provinces and Isle of Youth Special Municipality.

Results In 2001-2003, the NCR reported 1285 new cancer cases in the population aged $\leq 19$ years for an overall incidence of 13.9 per 100,000 population aged $\leq 19$ years (AAR). Highest risk was found in children aged $<1$ year with an ASR of 21.9 per 100,000 population aged $\leq 19$ years. Leukemias, lymphomas and central nervous system tumors comprised $61.1 \%$ of new cases, and geographic distribution of these diagnostic groups varied by sex. Childhood cancer risk was highest for males in Ciego de Avila, Villa Clara and the Isle of Youth Special Municipality and highest for females in Sancti Spíritus, Villa Clara and Cienfuegos.

Conclusions Incidence of childhood cancer in Cuba conforms to rates reported internationally and to the incidence pattern most common in Latin America. Further research is recommended to examine risk factors influencing geographical variations in incidence within Cuba.

Keywords: Pediatrics, cancer, incidence, risk, registries, epidemiology

The ICCC classifies neoplasms into 12 diagnostic groups and 47 subgroups. The 12 main groups are: I) leukemias; II) lymphomas and reticuloendothelial neoplasms; III) central nervous system (CNS) and miscellaneous intracranial and intraspinal neoplasms; IV) neuroblastoma and other peripheral nervous cell tumors; V) retinoblastoma; VI) renal tumors; VII) hepatic tumors; VIII) malignant bone tumors; IX) soft tissue and other extraosseous sarcomas; X) germ cell tumors, trophoblastic tumors, and neoplasms of gonads; $\mathrm{XI}$ ) other malignant epithelial neoplasms and malignant melanomas; and XII) other and unspecified malignant neoplasms.[7]

Several authors have proposed that the group aged 15-19 years be included in reports of childhood cancer data.[5,9-12] The World Health Organization (WHO) has also recommended that adolescence be considered age 10-19 years, divided for statistical purposes into 2 groups: early adolescence (age 10-14 years) and late adolescence (age 15-19 years).[13]

Cuba has maintained a National Cancer Registry (NCR) since 1964. Cancer incidence data is continuously and systematically gathered and processed, and used for statistical analysis applied to cancer control efforts and evaluation of the disease's impact on the community.[14,15] In the national public health system, all patients aged $\leq 19$ years are cared for in pediatric hospitals throughout the country, and all cases diagnosed and/or treated in Cuba's 9 pediatric oncology centers are classified according to the ICCC and reported to the NCR.

Nevertheless, in the Ministry of Public Health's Statistical Yearbook, cancer incidence in children aged $<15$ years (calculated 
using NCR provisional or definitive data) is described using the ICCC, and incidence in the population aged $\geq 15$ years is described by topography,[2] thus preventing an accurate epidemiological analysis of cancer risk in the "late adolescent" group (aged 15-19). In the present study, the population aged 15-19 years is included for the first time in an analysis of childhood cancer incidence in Cuba.

The objectives of this study are to describe childhood cancer incidence in the Cuban population aged $\leq 19$ years in 2001-2003 using the International Classification of Childhood Cancer, and to describe geographic distribution of incidence of childhood cancer in Cuba by sex and by the three diagnostic groups with highest incidence.

\section{METHODS}

A descriptive study of childhood cancer incidence was conducted using National Cancer Registry data for 2001-2003, the most recent period for which definitive figures are available. A 3-year period was selected to facilitate obtaining more precise estimates and to minimize the effect of random fluctuations from one year to another when calculating adjusted rates.

Incidence was analyzed by age group, and 5 age groups were established: <1, 1-4, 5-9, 10-14 and 15-19 years. Tumors were classified according to ICCC diagnostic groups and subgroups. Total number of cases registered in each diagnostic group during the study period was recorded, and the corresponding percentages of overall childhood cancer was calculated. Number of cases in each diagnostic group and subgroup was also recorded by age group, and the age-specific rate per 100,000 population aged $\leq 19$ years (ASR) was calculated by age group, as well as the age-adjusted rate to the standard world population aged $\leq 19$ years (AAR), using the direct standardization method.[15]

Once leukemias, lymphomas and CNS tumors were defined as the three diagnostic groups with highest childhood cancer incidence in Cuba, their AAR were used to analyze childhood cancer risk by sex and geographical distribution in the country's 14 provinces and Isle of Youth Special Municipality. AAR percentiles (P25, P50, P75) were calculated to establish 4 risk levels: low risk, $P<25$; intermediate risk, P25-50; high risk P51-75 and very high risk, P>75.

Incidence was presented in tables by diagnostic group and age group, and risk levels were represented by keyed shading of territories in a political map of Cuba.

\section{RESULTS}

In Cuba, 87,634 new cancer cases were reported to the National Cancer Registry in 2001-2003, of which 1285 were childhood cancers (Table 1). Cancer in the population aged $\leq 19$ years accounted for $1.5 \%$ of total cancer (annual average about 400 cases).

During the period analyzed, overall incidence was 13.9 per 100,000 population aged $\leq 19$ years (AAR). Highest risk was found in children aged $<1$ year with an ASR of 21.9 per 100,000 population aged $\leq 19$ years (Table 1 ).

Frequency was highest $(61.1 \%)$ in the three primary diagnostic groups: leukemias (Group I, 28.3\%), lymphomas (Group II, 18.6\%) and CNS tumors (Group III, 14.2\%) (Table 2). Among leukemias-
Table 1: Incidence of Childhood Cancer* in Cuba, 2001-2003

\begin{tabular}{|c|c|c|c|c|c|c|c|c|c|c|c|c|}
\hline \multicolumn{13}{|c|}{ Age Group (years) } \\
\hline \multicolumn{2}{|c|}{$<1$} & \multicolumn{2}{|c|}{$1-4$} & \multicolumn{2}{|c|}{$5-9$} & \multicolumn{2}{|c|}{$10-14$} & \multicolumn{2}{|c|}{ 15-19 } & \multicolumn{3}{|c|}{$0-19$} \\
\hline No. & ASR & No. & ASR & No. & ASR & No. & ASR & No. & ASR & No. & ASR & AAR \\
\hline 91 & 21.9 & 286 & 15.9 & 266 & 12.1 & 278 & 10.5 & 364 & 15.2 & 1285 & 13.6 & 13.9 \\
\hline
\end{tabular}

* Diagnostic Groups I-XII

ASR: Age-specific rate per 100,000 population aged $\leq 19$ years.

AAR: Age-adjusted rate, standard world population aged $\leq 19$ years.

Source: National Cancer Registry of Cuba

Table 2: Childhood Cancer by Diagnostic Group, Cuba, 2001-2003 \begin{tabular}{|l|l|l|}
\hline Diagnostic Group & Total Cases & \% Total
\end{tabular}

$\begin{array}{lll}\text { I. Leukemias } & 364 & 28.3\end{array}$

\begin{tabular}{l|l|l|}
\hline II. Lymphomas and reticuloendothelial & 239 & 18.6 \\
neoplasms
\end{tabular}

III. CNS and miscellaneous intracranial and intraspinal neoplasms

$182 \quad 14.2$

IV. Neuroblastoma and other peripheral nervous cell tumors

V. Retinoblastoma

VI. Renal tumors

VII. Hepatic tumors

VIII. Malignant bone tumors

\begin{tabular}{l|l|l|}
46 & 3.3
\end{tabular}

IX. Soft-tissue and other extra sarcomas

X. Germ-cell tumors, trophoblastic tumors, and neoplasms of gonads

XI. Other malignant epithelial neoplasms and malignant melanomas

$\begin{array}{ll}46 & 3.3 \\ 20 & 1.6\end{array}$

$65 \quad 5.1$

$13 \quad 1.0$

$90 \quad 7.0$

Other and unspecified malignant neoplasms

$63 \quad 4.9$

39

\section{All}

Source: National Cancer Registry of Cuba

$1285 \quad 100.0$

the diagnostic group with highest incidence (AAR 4.0) — the subgroup with highest incidence was lymphoid leukemias (AAR 2.7), predominantly in the group aged $1-4$ years (ASR 4.1) (Table 3).

Incidence of Diagnostic Group II cancers (lymphomas and reticuloendothelial neoplasms) was 2.5 (AAR). The group at highest risk was aged 15-19 years (ASR 3.2), and the diagnostic subgroup with highest incidence was non-Hodgkin lymphomas (AAR 1.2), predominantly in the groups aged 5-9 years (ASR 1.7) and 1-4 years (ASR 1.6). In the Hodgkin lymphoma subgroup, the group aged 15-19 years also had an ASR of 1.7 (Table 3).

Diagnostic Group III (CNS neoplasms) had the third highest incidence (AAR 2.0). Two age groups, aged 1-4 years and $<1$ year, shared highest risk (ASR 2.7 for both). Among the diagnostic subgroups, unspecified neoplasms had highest incidence (AAR 0.8), predominantly in children aged $<1$ year (ASR 1.2) (Table 3).

Incidence of diagnostic Group IV cancers (neuroblastoma and other peripheral nervous cell tumors) was 0.4 (AAR). Children aged $<1$ year were at highest risk overall (ASR 3.9) and for neuroblastoma (ASR 3.4), the subgroup with highest incidence (AAR 0.5 ). Incidence of retinoblastomas (Group V, AAR 0.3) was also highest in the same age group (ASR 1.9) (Table 4).

In Group VI (renal tumors), nephroblastoma (Wilms tumor) constituted the majority of cases (59/65 total) with an incidence of 0.8 (AAR) in both the diagnostic group and this subgroup. The group at highest risk for both was aged $<1$ year (ASR 2.4 and 2.2, respectively). 
Table 3: Incidence of Childhood Cancer in Cuba. Diagnostic Groups I-III, 2001-2003

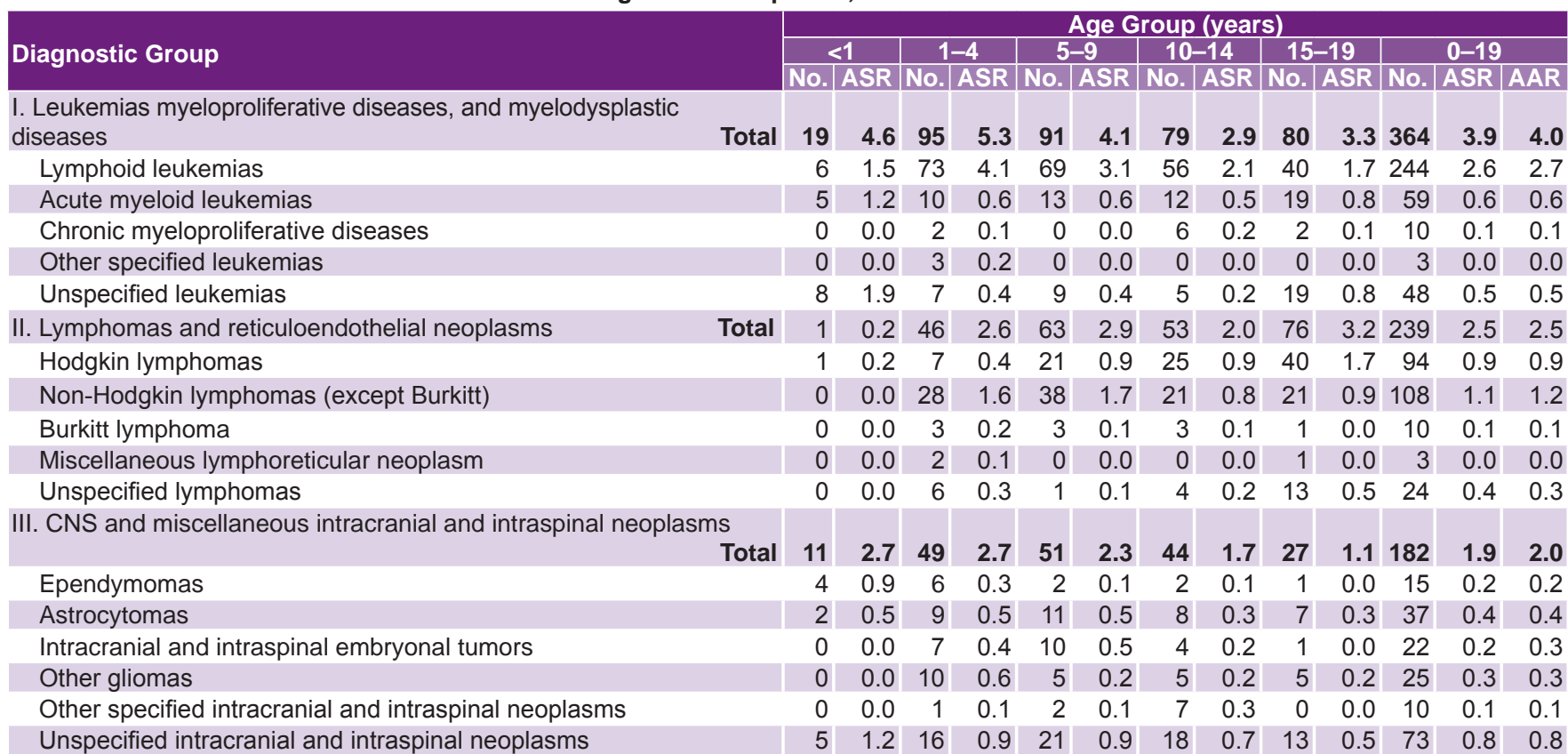

ASR: Age-specific rate per 100,000 population aged $\leq 19$ years.

AAR: Age-adjusted rate, standard world population aged $\leq 19$ years.

Source: National Cancer Registry of Cuba

Table 4: Incidence of Childhood Cancer in Cuba. Diagnostic Groups IV-VIII, 2001-2003

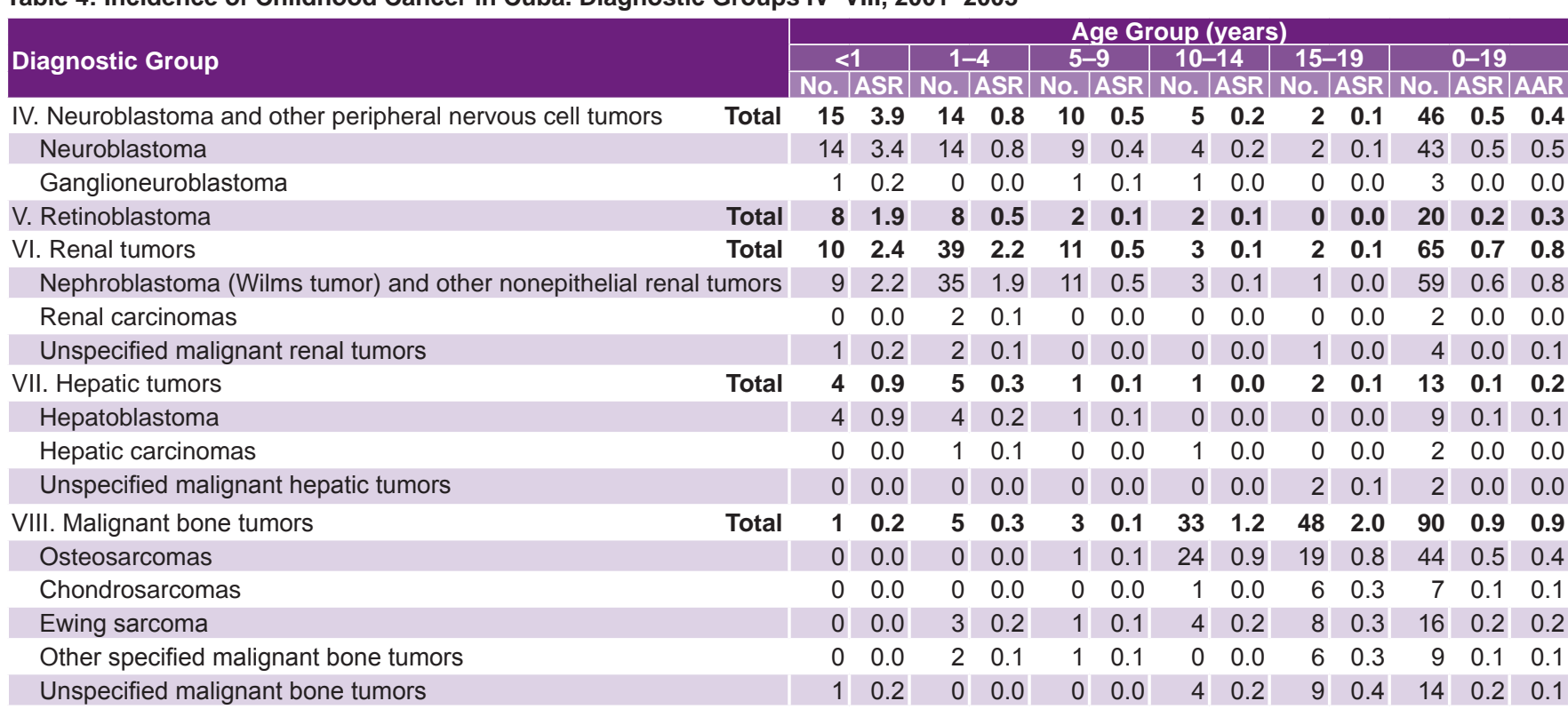

ASR: Age-specific rate per 100,000 population aged $\leq 19$ years.

AAR: Age-adjusted rate, standard world population aged $\leq 19$ years.

Source: National Cancer Registry of Cuba

Hepatic tumors (Group VII) was the diagnostic group with lowest incidence (AAR 0.2), affecting predominantly children aged $<1$ year with hepatoblastoma (ASR 0.9 overall and for this subgroup) (Table 4).

Malignant bone tumors (Group VIII) was the diagnostic group with fifth highest incidence (AAR 0.9), and the group most at risk was aged 15-19 years (ASR 2.0). Osteosarcoma was the diagnostic subgroup with highest incidence (AAR 0.4), predominantly in groups aged 10-14 (ASR 0.9) and 15-19 (ASR 0.8) (Table 4).
Soft tissue sarcomas (Group IX) had an incidence of 0.7 (AAR) with highest risk in the group aged $<1$ year (ASR 1.9). The diagnostic subgroups with highest incidence were other specified soft tissue sarcomas (AAR 0.4) followed by rhabdomyosarcomas (AAR 0.2). The group at highest risk for both other specified soft tissue sarcomas and rhabdomyosarcomas was aged $<1$ year (ASR 1.5 and 0.5, respectively) (Table 5).

Incidence of germ cell tumors, trophoblastic tumors and neoplasms of gonads (Group X) was 0.4 (AAR) and the age groups 


\section{Original Scientific Articles}

Table 5: Incidence of Childhood Cancer in Cuba. Diagnostic Groups IX-X, 2001-2003

\begin{tabular}{|c|c|c|c|c|c|c|c|c|c|c|c|c|c|}
\hline \multirow{3}{*}{ Diagnostic Group } & \multicolumn{13}{|c|}{ Age Group (years) } \\
\hline & \multicolumn{2}{|c|}{$<1$} & \multicolumn{2}{|c|}{$1-4$} & \multicolumn{2}{|c|}{$5-9$} & \multicolumn{2}{|c|}{$10-14$} & \multicolumn{2}{|c|}{ 15-19 } & \multicolumn{3}{|c|}{$0-19$} \\
\hline & No. & ASR & No. & ASR & No. & ASR & No. & ASR & No. & ASR & No. & ASR & AAR \\
\hline IX. Soft tissue and other extraosseous sarcomas & 8 & 1.9 & 12 & 0.7 & 15 & 0.7 & 10 & 0.4 & 18 & 0.8 & 63 & 0.7 & 0.7 \\
\hline Rhabdomyosarcomas & 2 & 0.5 & 7 & 0.4 & 1 & 0.1 & 2 & 0.1 & 3 & 0.1 & 15 & 0.2 & 0.2 \\
\hline $\begin{array}{l}\text { Fibrosarcomas, peripheral nerve sheath tumors, and other } \\
\text { fibrous neoplasms }\end{array}$ & 0 & 0.0 & 0 & 0.0 & 2 & 0.1 & 1 & 0.0 & 1 & 0.0 & 4 & 0.0 & 0.0 \\
\hline Kaposi sarcoma & 0 & 0.0 & 0 & 0.0 & 0 & 0.0 & 0 & 0.0 & 0 & 0.0 & 0 & 0.0 & 0.0 \\
\hline Other specified soft tissue sarcomas & 6 & 1.5 & 5 & 0.3 & 9 & 0.4 & 5 & 0.2 & 13 & 0.5 & 38 & 0.4 & 0.4 \\
\hline Unspecified soft tissue sarcomas & 0 & 0.0 & 0 & 0.0 & 3 & 0.1 & 2 & 0.1 & 1 & 0.0 & 6 & 0.1 & 0.1 \\
\hline Germ cell tumors, trophoblastic tun & & & & & & & & & & & & & \\
\hline gonads & 3 & 0.7 & 4 & 0.2 & 5 & 0.2 & 12 & 0.5 & 15 & 0.6 & 39 & 0.4 & 0.4 \\
\hline Intracranial and intraspinal germ cell tumors & 1 & 0.2 & 0 & 0.0 & 0 & 0.0 & 0 & 0.0 & 0 & 0.0 & 1 & 0.0 & 0.0 \\
\hline Malignant extracranial and extragonadal germ cell tumors & 1 & 0.2 & 2 & 0.1 & 0 & 0.0 & 1 & 0.0 & 1 & 0.0 & 5 & 0.1 & 0.1 \\
\hline Malignant gonadal germ cell tumors & 1 & 0.2 & 1 & 0.1 & 2 & 0.1 & 10 & 0.4 & 5 & 0.2 & 19 & 0.2 & 0.2 \\
\hline Gonadal carcinomas & 0 & 0.0 & 1 & 0.1 & 0 & 0.0 & 0 & 0.0 & 6 & 0.3 & 7 & 0.1 & 0.1 \\
\hline Other and unspecified malignant gonadal tumors & 0 & 0.0 & 0 & 0.0 & 3 & 0.1 & 1 & 0.0 & 3 & 0.1 & 7 & 0.1 & 0.1 \\
\hline
\end{tabular}

ASR: Age-specific rate per 100,000 population aged $\leq 19$ years.

AAR: Age-adjusted rate, standard world population aged $\leq 19$ years.

Source: National Cancer Registry of Cuba

Table 6: Incidence of Childhood Cancer in Cuba, Diagnostic Groups XI-XII, 2001-2003

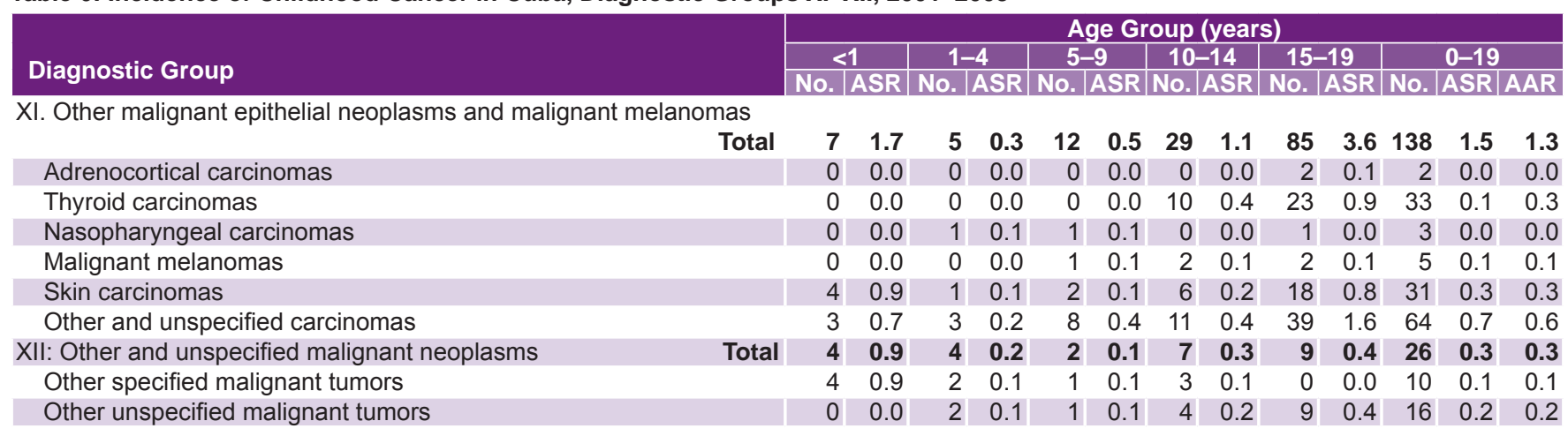

ASR: Age-specific rate per 100,000 population aged $\leq 19$ years.

AAR: Age-adjusted rate, standard world population aged $\leq 19$ years.

Source: National Cancer Registry of Cuba

most at risk were children aged $<1$ year (ASR 0.7) and 15-19 years (ASR 0.6). Malignant gonadal germ cell tumors was the diagnostic subgroup with highest incidence (AAR 0.2), predominantly in the group aged 10-14 years (0.4 ASR) (Table 5).

Group XI (other malignant epithelial neoplasms and malignant melanomas) was the diagnostic group with fourth highest overall incidence (AAR 1.3) and primary incidence in the group aged 15-19 years (ASR 3.6). The diagnostic subgroup with highest incidence was other and unspecified carcinomas (AAR 0.6), predominantly in the group aged $15-19$ years (ASR 1.6) (Table 6).

The last diagnostic group, other and unspecified malignant neoplasms (Group XII), had an incidence of 0.3 (AAR), with highest risk in the group aged $<1$ year ( 0.9 ASR). The diagnostic subgroup with highest incidence, however, was unspecified malignant tumors (0.2 AAR), predominantly in the group aged 15-19 years (0.4 ASR), while the group aged $<1$ year had higher risk of developing other specified malignant tumors (0.9 ASR).

Geographic distribution of the three childhood cancer diagnostic groups with highest incidence-leukemias, lymphomas and CNS tumors - varied by sex. Overall risk among males aged $\leq 19$ years was very high (AAR >24.94) in Ciego de Avila and Villa Clara Provinces and the Isle of Youth Special Municipality, and low
(AAR <21.30) in Guantánamo, Granma, Cienfuegos and Havana Provinces (Figure 1). Among females in the same age group, risk was very high (AAR >26.41) in Sancti Spíritus, Villa Clara and Cienfuegos Provinces, and low (AAR <17.99) in Las Tunas, Havana and Guantánamo Provinces, and the Isle of Youth Special Municipality (Figure 2).

Incidence of leukemias in males was very high (AAR >8.27) in Villa Clara, Santiago de Cuba and the Isle of Youth, and low (AAR $<4.87$ ) in Las Tunas, Sancti Spíritus, Havana City and Pinar del Río (Figure 3). Among females, leukemia incidence was very high (AAR >5.67) in Granma, Holguín and Ciego de Avila, and low (AAR <3.42) in Havana, Matanzas, Las Tunas and the Isle of Youth (Figure 4).

Lymphoma risk was very high for males (AAR >7.40) in Pinar del Río, Villa Clara and Ciego de Avila, and low (AAR <2.82) in Guantánamo, Las Tunas, Cienfuegos and Havana (Figure 5); for females, lymphoma risk was very high (AAR >4.31) in Camagüey, Sancti Spíritus and Villa Clara, and low (AAR <1.80) in Guantánamo, Havana, Pinar del Río and the Isle of Youth (Figure 6).

Risk of central nervous system tumors in males was very high (AAR >3.51) in Camagüey, Las Tunas and the Isle of Youth, and low (AAR <1.49) in Holguín, Ciego de Avila, Sancti Spíritus and 
Figure 1: Geographic Distribution of Childhood Cancer Incidence in Cuban Males, 2001 to 2003

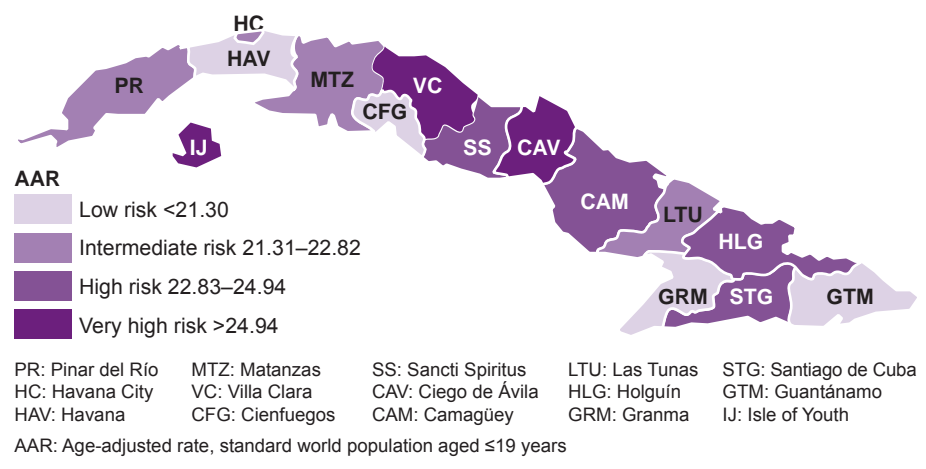

Figure 2: Geographic Distribution of Childhood Cancer Incidence in Cuban Females, 2001 to 2003

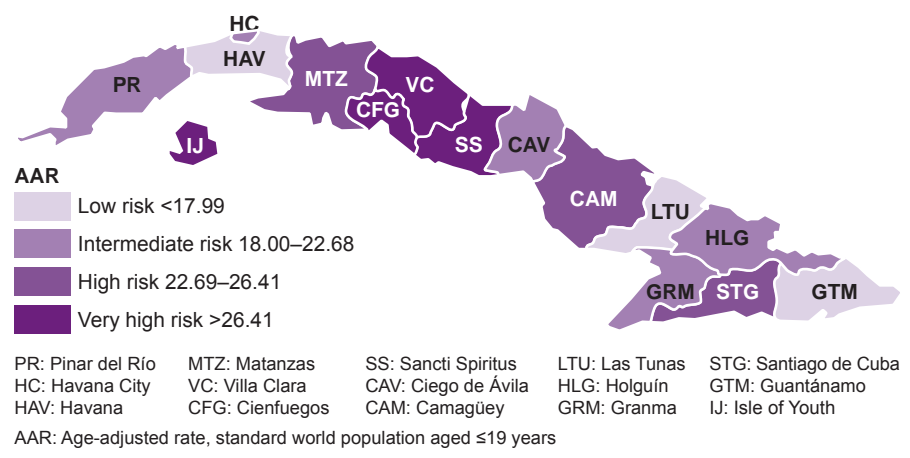

Figure 3: Geographic Distribution of Leukemia Incidence in Cuban Males Aged $\leq 19$ Years, 2001 to 2003

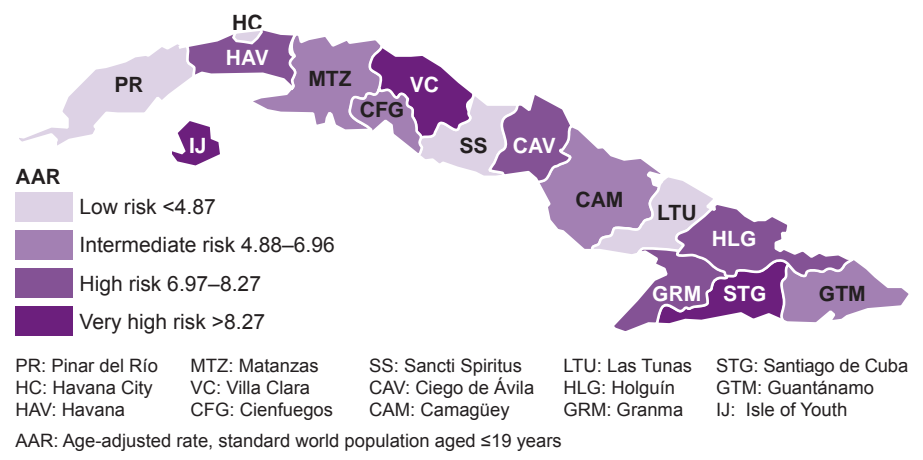

Figure 4: Geographic Distribution of Leukemia Incidence in Cuban Females Aged $\leq 19$ Years, 2001 to 2003

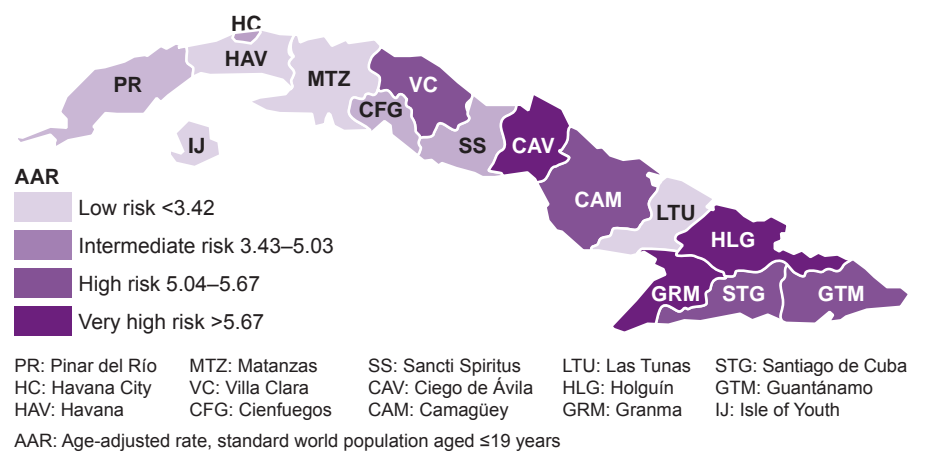

Figure 5: Geographic Distribution of Lymphoma and Reticuloendothelial Neoplasm Incidence in Cuban Males Aged $\leq 19$ Years, 2001 to 2003

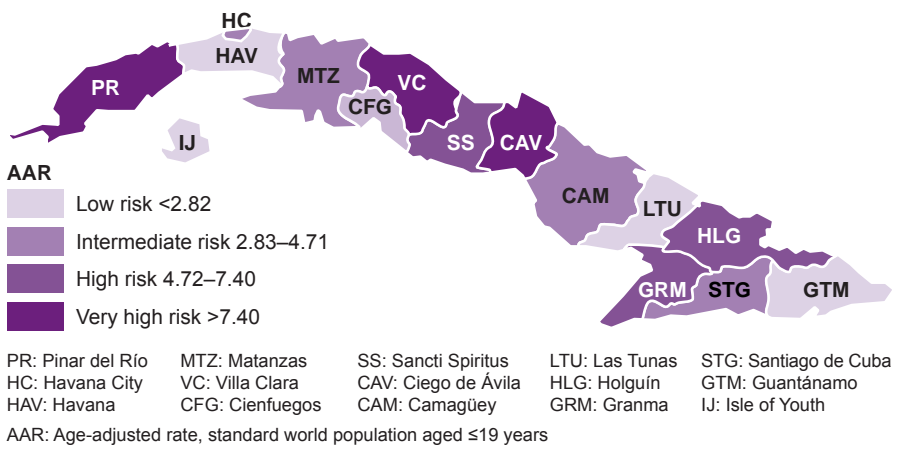

Figure 6: Geographic Distribution of Lymphoma and Reticuloendothelial Neoplasm Incidence in Cuban Females Aged $\leq 19$ Years, 2001 to 2003

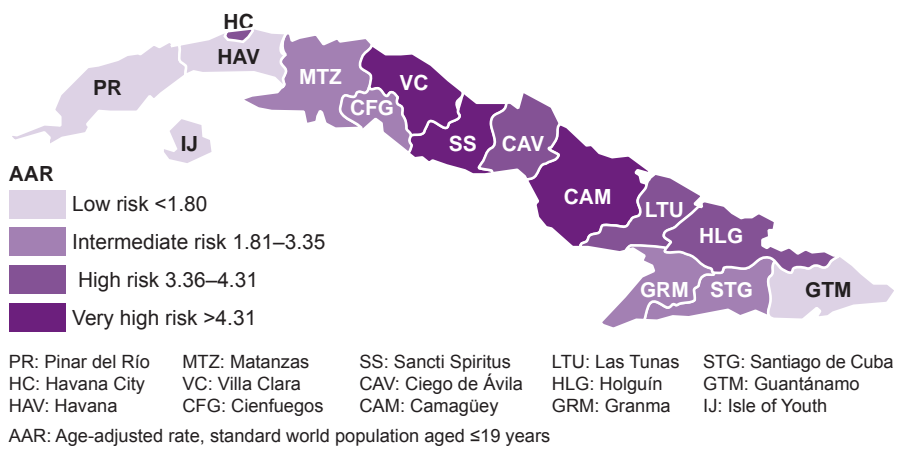

Figure 7: Geographic Distribution of CNS Tumor Incidence in Cuban Males Aged $\leq 19$ Years, 2001 to 2003

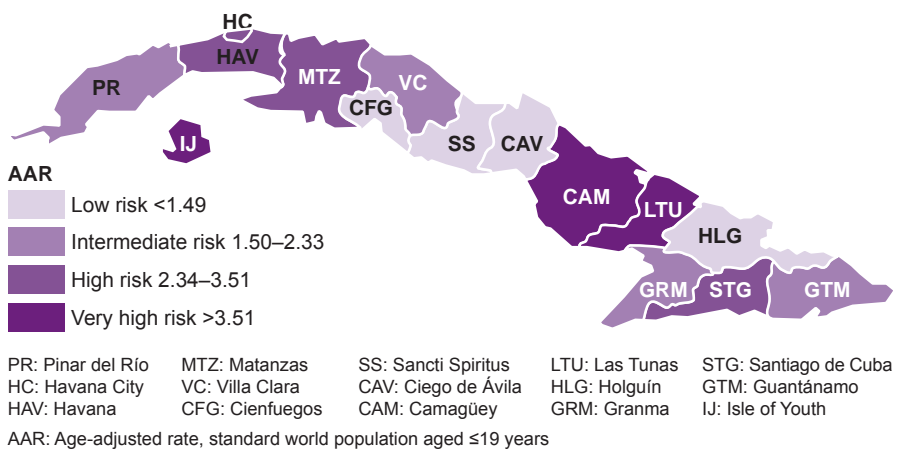

Figure 8: Geographic Distribution of CNS Tumor Incidence in Cuban Females Aged $\leq 19$ Years, 2001 to 2003

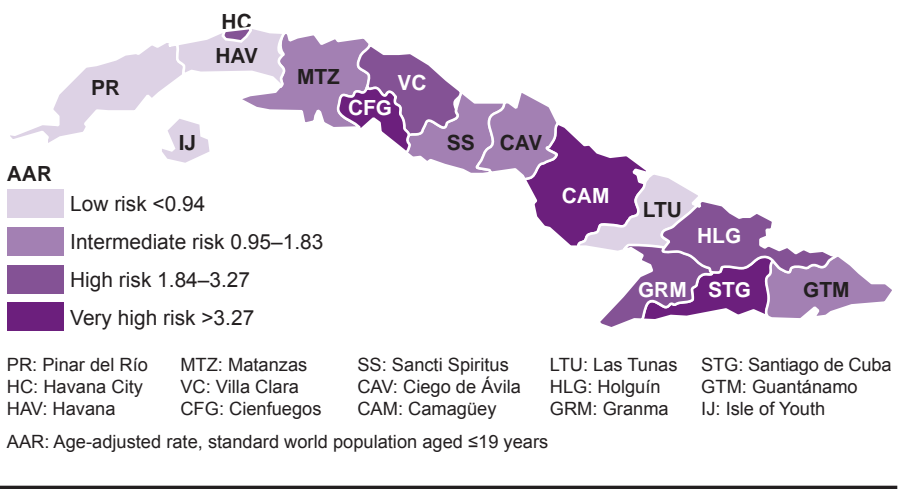


Cienfuegos (Figure 7). In females, risk was very high (AAR >3.27) in Camagüey, Santiago de Cuba and Cienfuegos, and low (AAR $<0.94$ ) in Las Tunas, Havana, Pinar del Río and the Isle of Youth (Figure 8).

\section{DISCUSSION}

The proportion of childhood cancer to total cancer found in this study is within the $1 \%-2 \%$ range considered normal internationally, $[8,15]$ and incidence rates, overall and by diagnostic group, are similar to those reported in the international literature.[1628] According to the International Agency for Research on Cancer (IARC), annual incidence worldwide is 100-150 per million population aged $\leq 19$ years with rates in Europe varying between 109 per million in England, 137 per million in France, 141 per million in Italy, 138 per million in Denmark. In Latin America, incidence is $91-106$ per million aged $<15$ years.[8] In the United States 8700 cases are reported annually in children aged $<15$ years and 12,400 cases in children and adolescents aged $<20$ years, equivalent to annual rates of 134 per million population aged $<15$ years and 149 per million population aged $<20$ years. [9] In some developing countries, rates as low as 45 per million population aged $<15$ years have been recorded, suggesting significant underreporting.[8]

Rates in Cuba differed from those reported internationally only in three diagnostic subgroups. Predominance of renal carcinomas has been reported internationally in the group aged 15-19 years, $[8,9]$ while in this study, incidence was very low, and the only cases registered were in the group aged 1-4 years. Other authors have reported that incidence of soft tissue sarcomas is highest in children aged $<10$ years with peaks at age 3-6 years for rhabdomyosarcoma and 15-19 years for other specified soft tissue sarcomas. $[6,10,29]$ These subgroups had highest incidence in Cuba, but predominantly in the group aged $<1$ year.

The three diagnostic groups found to have highest incidence in Cuba correspond to the three most frequent childhood cancers worldwide, $[1,30]$ and the order of frequency-leukemias first, lymphomas second, and CNS tumors third-matches the pattern most commonly found in Latin America.[6,8] Incidence patterns differ in other geographic regions, notably Europe and the United States, and Africa. In the former regions, leukemias are most common, followed by CNS tumors and lymphomas. In the United States, for example, these three diagnostic groups account for $63 \%$ of all cancers reported in children aged $<15$ years, in the following order: leukemias $30.2 \%$, CNS tumors $21.7 \%$, and lymphomas $10.9 \%$.[9] In Africa, however, lymphomas are the primary diagnostic group.[8]

Geographical and ethnic variations in childhood cancer incidence may be an expression of environmental risks or genetic factors, although family aggregation explains a very small number of cases. Such differences stand out in CNS tumors, which range from $10-40$ cases per million population aged $<15$ years, appearing much more frequently in whites and in high socioeconomically developed countries (especially in the Nordic European countries and the United States) than in blacks (in the United States and other developed countries), Asians, Hispanics, Africans, and in developing countries. Although risk factors to explain these differences have yet to be determined, it has been suggested that higher incidence of CNS tumors in developed countries is chiefly due to availability of more advanced diagnostic methods, whereas detection of these tumors is much lower in developing countries lacking diagnostic capacity.[1,31] Other variables, such as co-morbidity, variations in disease classification, and uncertainty about the reference population, may influence data quality in different geographic locations. [5,6,8,10,29,31]

Describing incidence of childhood cancer by skin color was not an objective of the present study because it was not reported with 2001-2003 data. This fact and differences found in childhood cancer risk in different parts of the country point to the need for more sociodemographic and biological research examining possible risk factors in order to develop adequate prevention strategies. A thorough analysis of cancer incidence and mortality trends in the Cuban population aged $\leq 19$ years is recommended. $-1 /$ -

\section{REFERENCES}

1. Día Mundial del Cáncer. Cáncer Infantil. Hoja Informativa [monograph on the Internet]. Asociación Española Contra el Cancer. Unión Internacional Contra el Cáncer. [cited 2008 Dec 10]. Available from: http://www.todocancer.com/ NR/rdonlyres/8E2FDE6E-EA5C-45FF-8BDEF47D77A1CE4B/0/HOJA_INF_4FEBRERO_NINOS.pdf

2. Anuario Estadístico de Salud 2008. Havana: Ministry of Public Health (CU), National Medical Records and Health Statistics Bureau; 2009. p. 60-2.

3. Menck HR, Phillips JL. Central cancer registries. In: Hutchinson CL, Menck HR, Burch M, Gottschalk R, editors. Cancer registry management: Principles and Practice. 2nd ed. lowa: Kendall/ Hunt Publishing; 2004. p. 403-39.

4. Wacker FF. Case Ascertainment. In: Hutchison CL, Menck HR, Burch M, Gottschalk R, editors. Cancer registry management: principles and practice. 2nd ed. lowa: Kendall/Hunt. Publishing; 2004. p. 109-16.

5. Cuevas-Urióstegui ML, Villasís-Keever MA, Fajardo-Gutiérrez A. Epidemiología del cáncer en adolescentes. Salud Publica Mex. 2003;45 Suppl 1:S115-S23.
6. Stiller C. Epidemiology of cancer in adolescents. Med Pediatr Oncol. 2002 Sep;39(3):149-55.

7. Steliarova-Foucher E, Stiller C, Lacour B, Kaatsch P. International Classification of Childhood Cancer, third edition. Cancer. 2005 Apr 1;103(7):1457-67.

8. Parkin DM, Kramárová E, Draper GJ, Masuyer E, Michaelis J, Neglia J, et al, editors. International Incidence of Childhood Cancer, Vol II. IARC Scientific Publication 144; 1998.

9. Cancer en niños. Tribuna Médica [serial on the Internet]. 2004 [cited 2008 Jul 15];104(5):[about 3 p.]. Available from:http://www.medilegis.com/ BancoConocimiento/T/TM104vol5-COL-Novedades/novedades.htm

10. Juárez-Ocaña $S$, Palma-Padilla $V$, GonzálezMiranda G, Carreón-Cruz R, Mejía-Aranguré JM, Fajardo-Gutiérrez A. Epidemiología del cáncer en adolescentes de 15 y 16 años. Rev Med Inst Mex Seguro Soc. 2008:46(4):361-6.

11. Ries LA, Miller RW, Smith MA. Cancer in children (ages 0-14 and ages 0-19). In: Miller BA, Ries LAG, Hankey BF, Kasary CL, Harras A, Devesa SS, et al., editors. USA-SEER Cancer Statistics Reviews: 1973-1990, National Cancer Institute.
Bethesda (MD): National Institutes of Health; 1993.

12. Vargas L. Cáncer en Pediatría. Aspectos generales. Rev Chil Pediatr. 2000 Jul;71(4):8-9.

13. Monroy AL, Velasco L. Fecundidad en la adolescencia. Causas, riesgos y opciones. Washington, DC: World Health Organization; 1988. p. 3.

14. Galán Y, Fernández L, Torres P, García M. Trends in Cuba's Cancer Incidence (1990 to 2003) and Mortality (1990 to 2007). MEDICC Review. 2009;11(3):27-33.

15. Rodríguez A, Martín A. El Registro Nacional de Cáncer de Cuba. Procedimientos y resultados. Rev Brasileira de Cancerologia. 2001;47(2):171-7.

16. Neglia JP, Robinson LL. Epidemiology of the childhood acute leukemias. Pediatr Clin North Am. 1988 Aug;35(4):675-92.

17. Shah A, Coleman MP. Increasing incidence of childhood leukaemia: a controversy re-examined. $\mathrm{Br} \mathrm{J}$ Cancer [serial on the Internet]. 2007 Aug 21 [cited 2007 Oct 8];97(7):[about 4 p.]. Available from: http://www.nature.com/bjc/journal/v97/n7/ full/6603946a.html

18. Terracini B, Maule MM. Aetiological clues from the descriptive epidemiology of childhood 
acute lymphatic leukaemia and other malignancies. J Epidemiol Community Health. 2007 Mar;61(3):180-1.

19. Ries LA, Miller RW, Smith MA. Cancer in children (ages 0-14 and ages 0-19). In: Miller BA, Ries LAG, Hankey BF, Kasary CL, Harras A, Devesa SS, et al., editors. USA-SEER Cancer Statistics Reviews: 1973-1990, National Cancer Institute. Bethesda (MD): National Institutes of Health; 1993. p. 1-15.

20. Macfarlane GJ, Evstifeeva T, Boyle P, Grufferman S. International patterns in the occurrence of Hodgkin's disease in children and young adult males. Int J Cancer. 1995 Apr 10;61(2):165-9.

21. Grufferman S, Gilchrist GS, Pollock BH. Socioeconomic status, the Epstein-Barr virus and risk of Hodgkin's disease in children. Leuk Lymphoma. 2001;42 Suppl 1: P-054.

22. Villarejo F, Martínez Lage JF. Tumores cerebrales en niños. Pediatr Integral. 2008;12(6):577-83.

23. Kaatsch $P$, Steliarova-Foucher E, Crocetti E, Magnani C, Spix C, Zambon P. Time trends of cancer incidence in European children (19781997). Report from the Automated Childhood Cancer Information System project. Eur J Cancer. 2006 Sep;42(13):1961-71.

24. Cancer.gov [homepage on the Internet]. USA: National Cancer Institute. [updated 2009 Dec 12; cited 2010 Jan]. Available from: http://www.cancer.gov/espanol/pdq/tratamiento/neuroblastoma/ patient/

25. Neuroblastoma. Medline Plus. Enciclopedia Médica [homepage on the Internet]. Maryland: U.S National Library of Medicine [updated 2008 Oct 6; cited 2009 Jan 29]. Available from: http:// www.nlm.nih.gov/medlineplus/spanish/ency/article/001408.htm

26. Rangel-Charqueño MG, Ordaz-Favila JC, Juárez-Echenique JC. Salvamento ocular en retinoblastoma. Rev Mex Oftalmol. 2004 MayJun;78(3):111-7.
27. Alvarado-Castillo B, Campos-Campos LE, Villavicencio-Torres A. Prevalencia de retinoblastoma del 2002 al 2006 en una unidad médica de alta especialidad. Rev Mex Oftalmol. 2007 NovDec;81(6):336-9.

28. Mejía-Aranguré JM, Beutelspacher-Vázquez $O$, Juárez-Ocaña $S$, Vázquez-Langle J, Martínez-García MC, Fajardo-Gutiérrez A. Tendencia de la incidencia de los tumores hepáticos en la infancia. Salud Publica Mex [serial on the Internet]. 2002 Mar-Apr [cited 2009 Aug 10];44(2):[about 7 p.] Available from: http://redalyc.uaemex.mx/redalyc/src/inicio/ArtPdfRed. jsp?iCve $=10644203$

29. Fajardo Gutiérrez A, Mejía Aranguré JM, Hernández Cruz L, Mendoza Sánchez HF, Garduño Espinosa J, Martínez García MC. Epidemiología descriptiva de las neoplasias malignas en niños. Pan Am J Public Health.1999;6(2):75-88.

30. Vargas L. Cáncer infantil en Chile. 10 años. Programa PINDA. Santiago de Chile: Ministry of Health (CL); 2000.

31. Steliarova-Foucher E, Stiller C, Kaatsch P, Berrino F, Coebergh JW, Lacour B, et al. Geographical patterns and time trends of cancer incidence and survival among children and adolescents in Europe since the 1970s (the ACCIS project): an epidemiological study. Lancet. 2004 Dec 11;364(9451):2097-105

\section{THE AUTHORS}

Priscila Torres Babié (Corresponding author: priscy@infomed.sld.cu), oncologist. Adjunct researcher and instructor, National Cancer Registry Department, National Oncology and Radiobiology Institute, Havana, Cuba.
Yaima Galán Alvarez, mathematician and master of public health. Associate researcher, associate professor and head of the National Cancer Registry Department, National Oncology and Radiobiology Institute, Havana, Cuba.

Juan Lence Anta, biostatistician and master of public health. Associate researcher, Clinical Trials Department, National Oncology and Radiobiology Institute, Havana, Cuba.

Mariela García, dentist and master of public health. Adjunct researcher, National Cancer Registry Department, National Oncology and Radiobiology Institute, Havana, Cuba.

Martha Lezcano Cicili, programmer, National Cancer Registry Department, $\mathrm{Na}$ tional Oncology and Radiobiology Institute, Havana, Cuba.

Leticia Fernández Garrote, lead researcher, National Oncology and Radiobiology Institute, Havana, Cuba.

Submitted: November 18, 2009

Approved for publication: March 16, 2010 